\title{
Local Government Debt and Regional Growth in Indonesia
}

\author{
$\underline{\text { Riznaldi Akbara }}^{\mathrm{a}}$ \\ ${ }^{a}$ Business School, University of Western Australia \\ Email: riznaldi.akbar@research.uwa.edu.au
}

\begin{abstract}
This study analyses the impact of local government debt on growth and attempt to determine the threshold level of local debt-to-GRP for 33 regions in Indonesia over the period of 2008 to 2013. To investigate the impact of the level of local debt-to-GRP (Gross Regional Product) on growth, we utilized a generalized economic growth model augmented with the debt variable. The empirical growth model is generally based on an equation that relates the real GRP per capita growth rate to the initial level of income per capita augmented with the variable of local government debt-to-GRP and a squared term of local government debt-to-GRP.
\end{abstract}

There are five control variables in this study. The first control variable is population growth rate to capture the effect of population in the region on local economic growth, which is expected to have a positive coefficient. A higher population creates higher aggregate demand in the region; therefore it is expected to have a positive effect on local growth. The second variable is the Human Development Index (HDI). The HDI is a composite index consisting of life expectancy, education and income indicator. The higher value of HDI represents better quality of life and education; thus it is expected to have positive sign. The third control variable is total investment of domestic and foreign investment. A higher value of investment would have a positive impact on infrastructure development as well as on the local growth, thus it is expected to have a positive coefficient. We also consider including fiscal capacity ratio (FISCI) as a control variable as it is used to assess the health status of local finance to take domestic and foreign loan. Even though, region with higher fiscal capacity ratio would have better ability to borrow and repay loan, we expect the sign of FISCI to be negative as region with higher fiscal capacity ratio is usually a more matured region with stable and lower local economic growth. The fifth control variable is the customer price index (CPI) to capture the impact of price level dynamics at the regional level. We expect the sign of CPI is negative, as rapid increase in the price level of goods and services will generally hamper local growth.

We first apply Ordinary Least Square (OLS) regression to examine the linear impact of the local debt-to-GRP variable on growth. We take into account of linear form of the local government debt-to-GRP ratio into equation. The coefficient of local debt-to-GRP is significant at the level of 1 per cent. To evaluate the nonlinear relationship between local debt and growth, we estimate a nonlinear regression model augmented with a squared term of debt variable. The coefficient of the debt variable and a squared term of debt variable are both significant at the level of 1 per cent and 5 per cent respectively. The sign of a squared term of debtto-GRP variable is also negative as we expect. The negative sign of a squared term of debt variable reflects the concavity or the inverted U-shape relationship between local government debt level and growth.

The Hausman test is used to determine the preferred panel model between Fixed Effect (FE) and Random Effect (RE). The results show that FE model is preferred over the RE. In the linear FE model, the coefficient of debt-to-GRP variable is significant at the level 1 per cent. In the nonlinear FE model, the debt-to-GRP variable is all significant at the level of 1 per cent and a squared term of debt-to-GRP is significant at the level of 10 per cent.

Our results suggest that there is a nonlinear relationship between local government debt and growth. The turning point or debt threshold ranges from 57 to 75 per cent. The coefficient of the quadratic form of local debt-to-GRP is a negative, indicating a concave or inverted U-shaped relationship between local debt and growth. The results confirm the theoretical assumption that at low debt levels the impact on growth is positive, but beyond the debt threshold an adverse effect on growth prevails.

Keywords: Local government debt, regional growth, debt threshold, panel model 


\section{INTRODUCTION}

The earlier literature on the relationship between debt and growth focused predominately on the adverse effects of the debt overhang (Krugman, 1988). Debt overhang describes a situation in which a country has a level of debt that exceeds its repayment ability, thus it would result adverse impact on investment and economic growth. As the size of debt increases, uncertainty about how government policy will respond in the future to meet debt-servicing obligations also increases. There might be expectations that the debt service obligations will be financed by distortionary measures as the debt increases (Agenor and Montiel, 1996). The debt Laffer curve also suggests that foreign borrowing will have positive impact on investment and growth up to a certain level, however beyond this level would result adverse impacts (Cohen, 1993). As the face value debt increases beyond a threshold level, the expected repayment also begins to fall.

There are numerousempirical studies analyzing the relationship between external debt and economic growth. Some show evidence for a non-linear impact and negative impact of external debt on economic growth beyond certain point (Patillo et al., 2002; Clement et al., 2003; Smyth and Sing, 1995; Zouhaier and Fatma, 2014). Some studies also analyzed a turning point or threshold at which the debt level has a negative impact on long-term growth. Reinhart and Rogoff (2010) found that economic growth deteriorated when government debt-to-GDP reaches 90 per cent in selected OECD countries. Patillo et al. (2002) found a lower threshold and suggested that average impact of debt becomes negative at about 35-40 per cent of GDP. More recently, Checherita-Westphal and Rother (2012) showed that a high level of debt-to-GDP ratio of above 90-100 per cent has a detrimental impact on growth. On the other hand, Schclarek (2004) did not find any evidences to support an inverted-U shape relationship between debt and growth.

The effect of local government debt on economic growth has not been widely discussed in the literature. Most studies assess the effect of public debt on economic growth at the country level (Baum et al., 2013; Checherita-Westphal and Rother, 2012; Clement et al., 2003; Patillo et al., 2002). Wu (2014) extended the literature by incorporating regional government debt variables into a growth equation for China. His empirical evidence confirmed the existence of a non-linear relationship between economic growth and local debt and found the threshold level of government debt in China to be much lower, at approximately 35 per cent, than figures observed in most studies of OECD countries.

This study aims to extend the work of Wu (2014) by presenting an empirical analysis for Indonesia's local government debt and its impact on local growth given the specific regional characteristics of Indonesia's. The remainder of the chapter outlines Indonesia's local debt profiles in Section 2. This is followed by a description of the methods in Section 3. The estimation results will be discussed in Section 4 and Section 5 draws conclusions.

\section{INDONESIA'S LOCAL DEBT PROFILES}

Local governments in Indonesia are allowed to take out long-term loans for capital development given several conditions. Local government borrowing should be used to finance infrastructure that directly generates sub national own source revenue. Another criterion is that the outstanding debt of a sub national government may not exceed 75 per cent of the previous year's general revenues (defined as all revenues except special purpose grants and emergency grants) and debt-service coverage ratio must be at least 2.5. In addition, local government cannot borrow more than the maximum amount determined by the central government, nor can they borrow while past loans remain in arrears. These strict regulations have limited local government and Regional Water Authorities borrowing and thus constrained public capital spending at local government level.

The vast majority of local government and local government enterprises (BUMDs) borrowing has been primarily channeled through two central government mechanisms: Subsidiary Loan Agreement (SLA) and the Regional Development Account (RDA). There has been only a very small amount of regional borrowing from other financial institutions, such as regional development, state, or commercial banks, and most of this has been to assist in the management of cash flow. SLA is the on-lending mechanism for major donor funds and it has been closely associated over the years with the Integrated Urban Infrastructure Development Programs (IUIDP) of the World Bank and the Asian Development Bank. RDA is the government's channel for lending state budget funds to local governments and BUMDs. The account has been used to finance regional infrastructure. The SLA and RDA loan mechanisms are both managed by the Ministry of Finance. 
The majority of local government borrowers are BUMDs, especially those located in the urban areas. BUMDs made up about two-thirds of total borrowing (Lewis, 2003). The majority of borrowing by BUMDs is used for water utility projects with a small residual allocated to recycling, garbage collection and disposal service operations. In the past years, local governments have not borrowed too much to finance their capital spending (Lewis, 2007). This low level of borrowing has had negative consequences for investment in infrastructure, particularly the delivery of water services. In this study, we use BUMDs debt as the proxy to reflect Indonesia's local government debt in relative to GRP.

\section{METHODS}

We investigate the relationship between local government debt-to-GRP (Gross Regional Product) ratio and per-capita GRP growth rate of 33 regions in Indonesia. We collected data from Indonesia's Bureau Statistical Office database covering the period of 2008 to 2013 with monthly observations. The empirical growth model is generally based on an equation that relates the real GRP per capita growth rate to the initial level of income per capita. This model is augmented to include the level of local government debt-to-GRP and a squared term of local government debt-to-GRP.

The dependent variable is the growth rate of GRP per capita and the explanatory variables are initial level of GRP per capita at constant 2000 prices, local government debt-to-GRP and a squared term of debt-to-GRP. A natural logarithm of lagged GDP per capita income is used as the initial per-capita income (Table 1).

Table 1. Variable Definition and Description.

\begin{tabular}{cl}
\hline Variable & Description \\
\hline$y_{i t}$ & GRP per capita growth rate in region $i$ at time $t$ \\
$\ln \left(Y_{i, t-5}\right)$ & Natural logarithm of 5-years lagged GRP per capita income in region $i$ at timet \\
$D_{i t}$ & Local government debt to GRP in region $i$ at time $t$ \\
$D_{i t}^{2}$ & A squared term local government debt to GRP in regioni at timet \\
$\mathrm{POPG}_{i t}$ & Population growth in region $i$ at time $t$ \\
$\mathrm{HDI}_{i t}$ & Human Development Index in regioni at timet \\
$\mathrm{INVGRP}_{i t}$ & Investment to GRP in region $i$ at time $t$ \\
$\mathrm{FISCI}_{i t}$ & Fiscal Capacity Ratio in region $i$ at time $t$ \\
$\mathrm{CPI}_{i t}$ & Consumer Price Index in regioni at time $t$ \\
\hline
\end{tabular}

We write our augmented growth model as follows:

$$
y_{i t}=\alpha+\beta \ln \left(Y_{i, t-k}\right)+\gamma D_{i t}+\emptyset\left(D_{i t}\right)^{2}+\Sigma \delta_{j} X_{i j t}+\mu_{i}+v_{t}+\varepsilon_{i t}
$$

Where $y_{i t}$ represents the regional growth rate of GRP per capita in region $i$ at time $t$, and $Y_{i, t-k}$ represents initial income per capita in region $i$ in period $t$ with the lagged term $k$. The study will use a five-year lag of initial income level as suggested by (Barro, 1991; Sala-i-Martin, 1997; Wu, 2014). Since we are interested in checking whether there exists a nonlinear impact of local debt on growth, we use a quadratic form of debt variable that will be captured by a squared term of the debt level $D_{i t}^{2}$ in the equation. $X$ is a set of control variables that may affect regional economic growth; $\mu_{i}$ is regional fixed effect; $v_{t}$ is time fixed effects; and $\varepsilon_{i t}$ is the error term. The error term is independent and identically distributed with mean zero and finite variance.

There are five control variables in this study. The first control variable is population growth (POPG) to capture the effect of population in the region on local economic growth, which is expected to have a positive coefficient. Higher population creates higher aggregate demand in the region; therefore it is expected to have a positive effect on local growth. The second variable is the Human Development Index (HDI). The HDI is a composite index consisting of life expectancy, education and income indicator. The higher value of HDI represents better quality of life and education; therefore it is also expected to have positive effect on the local growth. The third control variable is total investment of domestic and foreign investment (INVGRP). A higher value of investment would have a positive impact on infrastructure development as well as on local 
growth, thus it is expected to have a positive coefficient. We also consider including fiscal capacity ratio (FISCI) as a control variable as it is used to assess the health status of local finance to take domestic and foreign loan. This FISCI measure classifies regions into three categories: high, medium and low fiscal capacity. Even though, region with higher FISCI ratio would have better ability to borrow and repay loan, we expect the sign of FISCI is negative as region with higher fiscal capacity ratio is usually a more matured region with a stable and lower local economic growth. The indicator is calculated as follows:

$$
\text { Fiscal capacity ratio }=\frac{(\mathrm{PAD}+\mathrm{DBH}+\mathrm{DAU}+\mathrm{LP})-\mathrm{BP}}{\sum \text { Poor people }}
$$

Where PAD is actual local government revenue; $\mathrm{DBH}$ is local revenue from tax and nontax shares; DAU is general allocation; LP is specific allocation; and BP is personnel expense.

The fifth control variable is the customer price index (CPI) to capture the impact of price level dynamics at the regional level. The year 2007 is used as the base year. We expect the sign of CPI is negative, as rapid increase in the price level of goods and services will generally hamper local growth.

Table 2. Summary Statistics of the Variables.

\begin{tabular}{lllll}
\hline \multicolumn{1}{c}{ Variable } & Mean & Std. Deviation & Min & Max \\
\hline GRP Growth & 0.06 & 0.04 & -0.06 & 0.28 \\
LNGRP.L5 & 15.63 & 0.68 & 14.16 & 17.45 \\
Local debt-to-GRP & 0.16 & 0.15 & 0 & 0.86 \\
$\begin{array}{l}\text { Population Growth } \\
\text { Human Development }\end{array}$ & 0.02 & 0.01 & 0 & 0.05 \\
(HDI) & 0.72 & 0.03 & 0.64 & 0.79 \\
Investment/GRP & & & & 0.53 \\
Fiscal capacity ratio & 0.06 & 0.09 & 0 & 0.74 \\
Regional CPI & 0.08 & 0.12 & 0 & 1.58 \\
\hline
\end{tabular}

Source: author's own estimates

\section{ESTIMATION RESULTS}

\subsection{Linearity Test}

We first apply Ordinary Least Square (OLS) regression to investigate the linear impact of the local debt-toGRP variable on growth. We take into account of linear form of the local government debt-to-GRP ratio into equation. The initial income per capita is a 5-years lagged term as suggested by Checherita-Westphal and Rother (2012) and Wu (2014). Our control variables include population growth rate to reflect the size of population and workforce; human development index (HDI) as a proxy variable for human capital; investment ratio over GRP (INVGRP) to reflect infrastructure development; fiscal capacity ratio (FISCI) to reflect the financial position of the local finance; and consumer price index (CPI) to capture the impact of price level dynamics at the regional level. We used the following linear regression specification:

$$
\begin{aligned}
y_{i t}= & \alpha+\beta_{1} \ln \left(Y_{i, t-5}\right)+\gamma D_{i t}+\beta_{1} P O P G_{i t}+\beta_{2} H D I_{i t}+\beta_{3} I N V G R P_{i t}+\beta_{4} \text { FISCI }_{i t}+\beta_{5} C P I_{i t}+ \\
& \mu_{i}+v_{t}+\varepsilon_{i t}
\end{aligned}
$$

Before we perform the OLS estimation, we build correlation matrices to investigate relationships among explanatory variables. Of the explanatory variables: there are total 49-paired correlations of which 3 pairs have a generally high correlation of more than 50 per cent (Table 3 ). The correlation between a lagged term of income per capita (LNGRP.L5) and fiscal capacity ratio (FISCI) is relatively high (69 per cent); LNGRP.L5 and HDI (56 per cent); and HDI and FISCI (50 per cent). As we focus on the local debt-to-GRP (DEBTGRP) as our main variable of interest, the correlations coefficient between DEBTGRP and other explanatory variables are considerably low, thus reducing the risk of multicollinearity 
Table 3. Correlations of Explanatory Variables.

\begin{tabular}{|c|c|c|c|c|c|c|c|}
\hline & LNGRP.L5 & DEBTGRP & POPG & HDI & INVGRP & FISCI & CPI \\
\hline LNGRP.L5 & 1 & & & & & & \\
\hline DEBTGRP & -0.05 & 1 & & & & & \\
\hline POPG & 0.25 & 0.01 & 1 & & & & \\
\hline HDI & 0.56 & -0.14 & -0.11 & 1 & & & \\
\hline INVGRP & -0.06 & -0.04 & -0.05 & 0.14 & 1 & & \\
\hline FISCI & 0.69 & -0.12 & 0.09 & 0.50 & 0.13 & 1 & \\
\hline CPI & 0.03 & 0.20 & -0.10 & 0.14 & 0.25 & 0.16 & 1 \\
\hline
\end{tabular}

The result of the OLS baseline model is presented in the Table 4. The coefficient of local debt-to-GRP is significant at the level of 1 per cent (model 1 and 3). Of control variables, only population growth rate is significant at the level 5 per cent with expected positive sign (model 3), while the remaining control variables are not significant.

\subsection{Nonlinearity Test}

To evaluate the nonlinear relationship between local debt and growth, we estimate a panel growth regression model augmented with a squared term of debt variable. We considered all potential explanatory variables to assess the impact on the local growth. We include a squared term of debt with following model specification:

$$
\begin{aligned}
y_{i t}= & \alpha+\beta_{1} \ln \left(Y_{i, t-5}\right)+\gamma D_{i t}+\emptyset\left(D_{i t}\right)^{2}+\beta_{1} P O P G_{i t}+\beta_{2} H D I_{i t}+\beta_{3} I N V G R P_{i t}+\beta_{4} F I S C I_{i t}+ \\
& \beta_{5} C P I_{i t}+\mu_{i}+v_{t}+\varepsilon_{i t}
\end{aligned}
$$

The coefficient of the debt variable and a squared term of debt variable are both significant at the level of 1 per cent and 5 per cent respectively (model 2 and 4). The sign of a squared term of debt-to-GRP variable is negative as we expect. It could be interpreted that the negative sign of a squared term of debt variable reflects the concavity or the inverted U-shape relationship between regional debt level and growth. Of control variables, only the investment-to-GRP is significant at the level of 10 per cent with expected positive sign, while other control variables are not significant.

\subsection{Panel Data Estimation}

We run a Hausman test to determine the preferred model between Fixed Effect (FE) and Random Effect (RE). The results show that FE model is preferred over the RE as the $p$-value resulted from Hausman test is significant. In the linear FE model (model 5 and 7), the coefficient of debt-to-GRP variable is significant at the level 1 per cent, but the coefficient of the lagged term of initial income level is not significant. Of control variables, CPI and fiscal capacity ratio is significant at the level of 5 per cent and 10 per cent respectively. The sign of CPI is negative as we expect, as the rapid increase of price levels will generally hamper local growth. The sign of fiscal capacity ratio is also negative indicating region with low fiscal capacity ratio has ample opportunity to grow and enjoy higher growth. In the nonlinear FE model (model 6 and 8), the debt-toGRP variable is all significant at the level of 1 per cent. A squared term of debt-to-GRP is also significant at the level of 10 per cent (model 8). Of control variables, CPI and fiscal capacity ratio is significant at the level of 5 per cent with expected negative signs.

The results of our panel data estimation provide evidence for a statistically significant nonlinear relationship between local government debt and growth. The coefficient of the quadratic local debt-to-GRP variable is negative, indicating an inverted U-shaped relationship between local debt and growth. These results confirm the theoretical assumption that at the low level of debt the impact of debt on growth is positive, while beyond certain level or threshold a negative effect of debt prevails. 
Akbar, R., Local Government Debt and Regional Growth in Indonesia

Table 4. Estimation Results.

\begin{tabular}{|c|c|c|c|c|c|c|c|c|c|c|c|c|}
\hline & \multicolumn{4}{|c|}{ Pooled regression } & \multicolumn{4}{|c|}{ Fixed Effect (FE) } & \multicolumn{4}{|c|}{ Random Effect (RE) } \\
\hline & Model 1 & Model 2 & Model 3 & Model 4 & Model 5 & Model 6 & Model 7 & Model 8 & Model 9 & Model 10 & Model 11 & Model 12 \\
\hline Debt/GRP & $\begin{array}{l}0.066^{* * *} \\
(0.0001)\end{array}$ & $\begin{array}{l}0.15^{* * *} \\
(0.0002)\end{array}$ & $\begin{array}{l}0.07^{* * *} \\
(0.0000)\end{array}$ & $\begin{array}{l}0.16^{* * *} \\
(0.0001)\end{array}$ & $\begin{array}{l}0.08^{* * *} \\
(0.000)\end{array}$ & $\begin{array}{l}0.12^{* * *} \\
(0.003)\end{array}$ & $\begin{array}{l}0.07^{* * *} \\
(0.0000)\end{array}$ & $\begin{array}{l}0.15^{* * *} \\
(0.001)\end{array}$ & $\begin{array}{l}0.14^{* * *} \\
(0.0001)\end{array}$ & $\begin{array}{l}0.10^{* *} \\
(0.05)\end{array}$ & $\begin{array}{l}0.07^{* * *} \\
(0.0000)\end{array}$ & $\begin{array}{l}0.16^{* * *} \\
(0.0001)\end{array}$ \\
\hline$(\text { Debt/GRP })^{\wedge} 2$ & & $\begin{array}{l}-0.14^{* *} \\
(0.02)\end{array}$ & & $\begin{array}{l}-0.15^{* *} \\
(0.02)\end{array}$ & & $\begin{array}{l}-0.08 \\
(0.21)\end{array}$ & & $\begin{array}{l}-0.13^{*} \\
(0.07)\end{array}$ & & $\begin{array}{l}-0.08 \\
(0.27)\end{array}$ & & $\begin{array}{l}-0.16^{* *} \\
(0.02)\end{array}$ \\
\hline LNGRP.L5 & $\begin{array}{l}-0.006^{*} \\
(0.08)\end{array}$ & $\begin{array}{l}-0.004 \\
(0.27)\end{array}$ & $\begin{array}{l}-0.005 \\
(0.36)\end{array}$ & $\begin{array}{l}-0.0007 \\
(0.90)\end{array}$ & $\begin{array}{l}-0.0001 \\
(0.97)\end{array}$ & $\begin{array}{l}-0.07^{* *} \\
(0.02)\end{array}$ & $\begin{array}{l}-0.004 \\
(0.49)\end{array}$ & $\begin{array}{l}0.009 \\
(0.17)\end{array}$ & $\begin{array}{l}-0.004 \\
(0.26)\end{array}$ & $\begin{array}{l}-0.006 \\
(0.27)\end{array}$ & $\begin{array}{l}-0.005 \\
(0.35)\end{array}$ & $\begin{array}{l}-0.0007 \\
(0.90)\end{array}$ \\
\hline POPG & & & $\begin{array}{l}0.58^{* *} \\
(0.03)\end{array}$ & $\begin{array}{l}0.41 \\
(0.14)\end{array}$ & & & $\begin{array}{l}0.30 \\
(0.030)\end{array}$ & $\begin{array}{l}0.17 \\
(0.56)\end{array}$ & & & $\begin{array}{l}0.58^{* *} \\
(0.03)\end{array}$ & $\begin{array}{l}0.41 \\
(0.14)\end{array}$ \\
\hline HDI & & & $\begin{array}{l}-0.002 \\
(0.98)\end{array}$ & $\begin{array}{l}-0.03 \\
(0.574)\end{array}$ & & & $\begin{array}{l}0.007 \\
(0.95)\end{array}$ & $\begin{array}{l}-0.02 \\
(0.83)\end{array}$ & & & $\begin{array}{l}0.001 \\
(0.98)\end{array}$ & $\begin{array}{l}-0.03 \\
(0.74)\end{array}$ \\
\hline INV/GRP & & & $0.04(0.16)$ & $\begin{array}{l}0.05^{*} \\
(0.06)\end{array}$ & & & $\begin{array}{l}0.02 \\
(0.61)\end{array}$ & $\begin{array}{l}-0.03 \\
(0.83)\end{array}$ & & & $\begin{array}{l}0.04 \\
(0.15)\end{array}$ & $\begin{array}{l}0.06^{* *} \\
(0.05)\end{array}$ \\
\hline FISCI & & & $\begin{array}{l}-0.02 \\
(0.34)\end{array}$ & $\begin{array}{l}-0.04 \\
(0.13)\end{array}$ & & & $\begin{array}{l}-0.05^{*} \\
(0.08)\end{array}$ & $\begin{array}{l}-0.07^{* *} \\
(0.03)\end{array}$ & & & $\begin{array}{l}-0.02 \\
(0.32)\end{array}$ & $\begin{array}{l}-0.04 \\
(0.12)\end{array}$ \\
\hline CPI & & & $\begin{array}{l}0.02 \\
(0.24)\end{array}$ & $\begin{array}{l}0.02 \\
(0.32)\end{array}$ & & & $\begin{array}{l}-0.13^{* *} \\
(0.04)\end{array}$ & $\begin{array}{l}-0.13^{* *} \\
(0.04)\end{array}$ & & & $\begin{array}{l}0.02 \\
(0.22)\end{array}$ & $\begin{array}{l}0.02 \\
(0.31)\end{array}$ \\
\hline Constant & $\begin{array}{l}0.17^{* * *} \\
(0.003)\end{array}$ & $\begin{array}{l}0.14^{* * *} \\
(0.01)\end{array}$ & $\begin{array}{l}0.11 \\
(0.22)\end{array}$ & $\begin{array}{l}0.06 \\
(0.52)\end{array}$ & $\begin{array}{l}0.07 \\
(0.22)\end{array}$ & $\begin{array}{l}1.19^{* *} \\
(0.02)\end{array}$ & $\begin{array}{l}0.17 \\
(0.23)\end{array}$ & $\begin{array}{l}0.12 \\
(0.38)\end{array}$ & $\begin{array}{l}0.14^{* * *} \\
(0.01)\end{array}$ & $\begin{array}{l}0.17^{* *} \\
(0.05)\end{array}$ & $\begin{array}{l}0.11 \\
(0.20)\end{array}$ & $\begin{array}{l}0.06 \\
(0.51)\end{array}$ \\
\hline Hausman test & & & & & $\begin{array}{l}11.71^{* * *} \\
(0.003)\end{array}$ & $\begin{array}{l}11.38^{*} \\
(0.009)\end{array}$ & $\begin{array}{l}27.89^{* * *} \\
(0.0002)\end{array}$ & $\begin{array}{l}27.60^{* * *} \\
(0.0006)\end{array}$ & & & & \\
\hline
\end{tabular}

Source: author's own estimates

Notes:

*Significant at $10 \%$

${ }^{* *}$ Significant at $5 \%$

${ }^{* * *}$ Significant at $1 \%$

Number in parentheses indicates p-value

\subsection{Debt Threshold}

As our results suggest nonlinear relationship between growth and local government debt in Indonesia, we also need to calculate threshold of the local debt to show at what level the debt become contra productive to the overall economy. The computation involves two processes. The first step is to take the first derivative of the equation with respect to the debt-to-GRP ratio. The second step is to ensure that the turning point is at the maximum point (Kumara and Cooray, 2013).

$$
\frac{\partial y_{i t}}{\partial D_{i t}}=\gamma+2 \varnothing\left(D_{i t}\right)=0
$$

The first-order derivative suggests a turning point of the local debt-to-GRP, while the second order derivative ensures that there is a maximum at the turning point. Our results show that the turning point of the local debtto-GRP in Indonesia is estimated between 57 to 75 per cent. It implies that the local government debt-to-GRP above this threshold would have an adverse impact on the regional growth. 


\section{CONCLUSION}

This study analyses the impact of local government debt on growth and attempt to determine the threshold level of local debt-to-GRP for 33 regions in Indonesia over the period of 2008 to 2013. To investigate the impact of the level of local debt-to-GRP on growth, we utilized a generalized economic growth model augmented with the debt variable. Our results suggest that there is a nonlinear relationship between growth and local government debt. The turning point or debt threshold ranges from 57 to 75 per cent. The coefficient of the quadratic form of local debt-to-GRP is a negative, indicating a concave or inverted Ushaped relationship between local debt and growth. The results confirm the theoretical assumption that at low debt levels the impact on growth is positive, but beyond the debt threshold an adverse effect on growth prevails.

\section{REFERENCES}

Agenor, P.R., Montiel, P. (1996), Development Macroeconomics, Princeton, New Jersey: Princeton University Press

Barro, R.J. (1991), "Economic growth in a cross section of countries", Quarterly Journal of Economics, vol. 106 , issue. $2,407-443$

Baum, A., Checherita-Westphal, C., Rother, P. (2013), "Debt and growth: new evidence for the Euro Area", Journal of International Money and Finance, vol. 32, 809-821

Checherita-Westphal, C., Rother, P. (2012). "The impact of high government debt on economic growth and its channels: an empirical investigation for the Euro area". European Economic Review, vol.56, issue 7,1392-1405

Clement, B., Bhattacharya, R., Nguyen, T.Q. (2003), "External debt, public investment, and growth in lowincome countries", IMF Working paper 03/249

Cohen, D. (1993), "Low investment and large LDC debt in the 1980s", American Economic Review, vol. 83, issue. 3, 437-49

Krugman, P. (1988), "Financing vs. forgiving a debt overhang: some analytical issues", NBER

Kumara, H., Cooray, N.S. (2013), "Public debt and economic growth in Sri Lanka: is there any threshold level for public debt?", International University of Japan

Lewis, B.D. (2003)," Local government borrowing and repayment in Indonesia: does fiscal capacity matter?",World Development, vol. 31, issue 6, 1047-1063

Lewis, B.D. (2007),"'On-lending in Indonesia: past performance and future prospects", Bulletin of Indonesian Economic Studies, vol.43, issue 1, 35-57

Patillo, C.A., Poirson, H., Ricci, L.A. (2002), "External debt and growth", IMF Working Paper 02/69, Washington DC

Reinhart, C.M., Rogoff, K.S. (2010), "Growth in a time of debt", American Economic Review, vol. 110, issue. 2, 573-578

Sala-i-Martin, X.X. (1997), "I just ran two million regression”, American Economic Review, vol. 87, issue 2, $178-183$

Schclarek, A. (2004), "Debt and economic growth in developing and industrial countries", Lund University Department of Economics Working Paper, vol. 34

Smyth, D., Hsing, Y. (1995). "In search of an optimal debt ratio for economic growth", Contemporary Economic Policy, vol. 13,51-59

Wu, Yanrui. (2014), "Local government debt and economic growth in China, BOFIT Discussion Paper No.20/2014

Zouhaier, H., Fatma, M. (2014), "Debt and economic growth", International Journal of Economics and Financial Issues, vol.4, issue 2, 440-408. 